\title{
Anunciação de mundos, sonhos e saberes ancestrais: narrativas de uma juremeira da cidade de João Pessoa
}

Maria Gomes de Medeiros donamariamedeiros@gmail.com da Universidade Federal da Paraíba, João Pessoa, Paraíba, Brasil.

\section{Ana Cristina Marinho} anamanho@gmail.com

Programa de Pós-Graduação em Letras da Universidade Federal da Paraíba, João Pessoa, Paraíba, Brasil.

\begin{abstract}
RESUMO
O presente trabalho envolve pesquisas sobre a história de vida e os percursos da juremeira Inês dos Santos na cidade de João Pessoa, na Paraíba. Interessa-nos entender, a partir da experiência de Inês, como as narrativas coletivas de terreiros de Jurema e Umbanda (re)constroem a memória mítica (Sodré, 2018) de populações em contextos de diáspora afro-ameríndia nesta cidade. Nesse sentido, interessam-nos também as roupas e comidas ritualísticas enquanto construções narrativas. Nos valemos do conceito de Literatura Menor (DELEUZE e GUATARI, 1995) para entendermos as narrativas de Inês, conforme seus imperativos éticos e políticos, e utilizamos, ainda, conceitos dos estudos culturais, feministas e decoloniais, autores e autoras que se debruçaram sobre temas como "colonialidade" e "decolonialidade", "diáspora", "epistemicídio", "justiça social e cognitiva" (FANON, 1968; QUIJANO, 2005; SOUSA SANTOS, 2019). Adotamos metodologias de pesquisa de campo voltadas para a história oral, como técnica de entrevista, e o testemunho, como postura social e política para que, ao final, possamos traçar uma cartografia da cidade construída a partir da voz e do corpo dessa mulher negra, filha de Oxum e devota dos encantados da Jurema.
\end{abstract}

PALAVRAS-CHAVE: Narrativa oral. Jurema sagrada. Umbanda. Cartografia. 


\section{INTRODUÇÃO}

As religiões de matrizes afro-ameríndias emergem no contexto colonial brasileiro como um exemplo de resistência dos povos colonizados e escravizados, constituindo-se num universo múltiplo e multifacetado de saberes e práticas que, historicamente, resistiram às formas de dominação europeias que impuseram a moral e ética cristãs como preceitos de humanidade. As populações de origens africanas que foram sequestradas de seus países de origem e aqui escravizadas e a população originária foram, portanto, relegadas à condição de sub-humanidade.

Os europeus forçaram os colonizados a aprender parcialmente a cultura dos dominadores em tudo o que fosse útil para a reprodução da dominação, seja no campo da atividade material, tecnológica, seja no campo da atividade subjetiva, especialmente religiosa. É este o caso da religiosidade judaico-cristã. Deste processo resultou a colonização das perspectivas cognitivas, das formas de produção de sentido através de experiências materiais, intersubjetivas e culturais, conforme explica Aníbal Quijano (2005).

Como sugere Boaventura de Sousa Santos: "[...] o mundo colonial, o mundo da sociabilidade colonial, é o mundo do "eles", aqueles aos quais é inimaginável a existência de qualquer equivalência ou reciprocidade, uma vez que não são totalmente humanos" (2019, p. 43). Nesse sentido, a precariedade imposta à população de terreiro é fruto de uma tentativa de desumanização desta população por meio de políticas de estado racistas. A tentativa de destruir todos os referenciais culturais do povo negro e indígena é um exercício de manutenção do seu genocídio.

Sobre os processos de construção de precariedade é interessante pensar nas reflexões de Judith Butler (2015, p. 117) que entende que "alguns humanos consideram natural sua condição de humanidade, ao passo que outros batalham para garantir o acesso a ela", assim sendo, o "termo humano é constantemente duplicado, expondo a idealidade e o caráter coercitivo da norma: alguns humanos podem ser qualificados como humanos, outros, não".

Um dos exemplos de efetivação de uma política de construção de precariedade e coerção da sociedade contra o povo negro é a estruturação da polícia brasileira, mobilizada para fechar e destruir os terreiros das religiões de matrizes africanas e ameríndias. A força policial é um instrumento imprescindível ao extermínio simbólico e físico da população negra na sociedade brasileira.

A tradição de criminalização destas religiões é uma peça-chave para entendermos como se efetiva e perdura o poder conforme os padrões coloniais escravocratas na sociedade brasileira. Aníbal Quijano (2005), ao analisar as configurações de poder que atravessam as relações sociais, entende que a classificação social da população mundial, a partir da ideia de raça, é uma expressão evidente da dominação colonial que perdura na sociedade latinoamericana. Já Frantz Fanon (1968), em Os Condenados da Terra, aponta que o poder policial emerge na sociedade colonial exatamente como a linha abissal em que a mobilização de forças de repressão se expressa. Para os povos colonizados não existe mediação, a violência policial é a linguagem utilizada no diálogo entre colono e colonizado.

No entanto, mesmo diante do contexto de violência que essa população enfrenta, a permanente retomada das práticas religiosas se inscreve no conjunto 
de tradições do povo negro e do povo indígena como signo de resistência e criatividade muito potente. São as reflexões do teórico cultural e sociólogo jamaicano Stuart Hall (2005) que possibilitam pensar e problematizar as identidades em diáspora, bem como as mediações que povos subalternizados traçam com a sua cultura:

A cultura é uma produção. Tem sua matéria-prima, seus recursos, seu "trabalho produtivo". Depende de um conhecimento da tradição enquanto "o mesmo em mutação" e de um conjunto efetivo de genealogias. Mas o que esse "desvio através de seus passados" faz é nos capacitar, através da cultura, a nos produzir a nós mesmos de novo, como novos tipos de sujeitos. Portanto, não é uma questão do que as tradições fazem de nós, mas daquilo que nós fazemos das nossas tradições. (HALL, 2005, p. 44)

Destarte, entendemos que estudar e buscar compreender o contexto de produção de conhecimento e as narrativas que dão sentido às experiências dos povos afro-ameríndios nos possibilita construir ferramentas eficazes contra a perpetuação dos modos de dominação que se utilizam da destruição da experiência cultural e subjetiva de contingentes significativos da população brasileira.

Tendo em vista a forma como, tradicionalmente, a academia relegou ao lugar de marginalização saberes e narrativas advindas de povos marginalizados socialmente, Boaventura de Sousa Santos (2007) argumenta que a ciência cartesiana se desenvolveu no sentido de estabelecer-se como único conhecimento capaz de entender a realidade do mundo:

Refiro-me aos conhecimentos populares, leigos, plebeus, camponeses, ou indígenas do outro lado da linha. Eles desaparecem como conhecimentos relevantes ou comensuráveis por se encontrarem para além do universo do verdadeiro e do falso. É inimaginável aplicar-lhes não só a distinção científica entre verdadeiro e falso, mas também as verdades inverificáveis da filosofia e da teologia que constituem o outro conhecimento aceitável deste lado da linha. Do outro lado da linha, não há conhecimento real; existem crenças, opiniões, magia, idolatria, entendimentos intuitivos ou subjectivos, que, na melhor das hipóteses, podem tornar-se objectos ou matéria-prima para a inquirição científica. (SOUSA SANTOS, 2007, p.5)

O epistemicídio contra o conhecimento de povos historicamente oprimidos na sociedade é uma forma de perpetuar injustiças sociais e cognitivas. Entendemos que, apesar do conhecimento científico hegemônico ter sua importância, a diversidade de experiência do mundo não pode ser apreendida quando a enxergamos apenas através das lentes do conhecimento acadêmico, branco e eurocêntrico.

Dentro do panorama dos estudos que se debruçaram sobre as religiões de matrizes afro-ameríndias, escolhemos nos ater ao contexto paraibano da Jurema Sagrada, ou ainda da Jurema cruzada com a Umbanda. "O culto da Jurema é uma prática religiosa de tradição indígena, especialmente das tribos do Nordeste, 
vinculado à árvore do mesmo nome (jurema), a qual possui seu habitat no agreste e caatinga nordestina" (LIMA SANTOS, 2008, p. 01).

O cruzamento da Jurema com a Umbanda na Paraíba é fruto de um arranjo que os povos de terreiro fizeram quanto ao culto da Jurema, no qual as mesas de Catimbós eram criminalizadas. Foi a partir da expansão da Umbanda e da militância organizada do povo negro contra a criminalização de sua fé que o arranjo se deu, conforme elucida Idalina Lima Santos (2008):

Em meados do século XX, no Estado paraibano, ocorre a aproximação do Catimbó com a Umbanda em virtude do movimento de expansão desta pelo país. Assim, foi se delineando a Umbanda cruzada com Jurema como resultado da junção dos rituais da tradição juremeira/catimbozeira com a Umbanda trazida oficialmente para o referido Estado nos fins de 1960. Até essa época predominava na Paraíba a prática do Catimbó, tratado como caso de polícia. Os catimbozeiros ou juremeiros desejosos de se libertarem da pressão policial aceitaram se engajar na estrutura da nascente Federação dos Cultos Africanos do Estado da Paraíba, encampadora da doutrina umbandista. Contudo, a forte influência da jurema se fez presente na reorganização sincrética dos elementos religiosos da umbanda paraibana. $(2008$, p.3)

Tendo em vista a dimensão de forte criminalização que os juremeiros/catimbozeiros enfrentaram no contexto local da Paraíba, entendemos que as produções de conhecimento advindas destas experiências promovem justiça cognitiva sobre a temática invisibilizada, até mesmo dentro dos estudos das religiões afro-brasileiras, segundo Sampaio (2015):

Nesse contexto, a Jurema e o Catimbó, presentes no nordeste brasileiro, especialmente na Paraíba, Rio Grande do Norte e Pernambuco, foram relegadas não sendo tomadas como objeto de estudo. Devido à concentração dos estudos na tradição jeje-nagô, o interesse pela Jurema ainda se mostra mais tardio se comparado às demais religiões afro-brasileiras, pois mesmo sua presença sendo notada nos denominados Candomblés de Caboclo pelos autores pioneiros, passa, ainda assim, praticamente ignorada ou despercebida por esses autores. $(2015$, p. 04)

Foi pensando justamente neste processo de reelaboração dos cultos afroameríndios do nordeste brasileiro que Luiz Assunção (2011) discorreu sobre a nova jurema, que seriam os elementos tradicionais de origem indígena em terreiros de umbanda. Estes elementos seriam o culto às entidades espirituais identificadas como pertencentes ao universo da jurema: caboclos, índios e mestres.

É neste sentido que o nosso interesse se volta para a narrativa de vida de Inês dos Santos, antiga juremeira de João Pessoa, e sua relação com a cidade e a forma como o seu relato é (re)construído cotidianamente como fruto dessa relação. Analisaremos como a memória mitológica (Sodré, 2018) desta senhora constrói espaços culturais outros, além dos que lhes foram imputados pela dinâmica racializada e de forte herança colonial da cidade de João Pessoa. 
Nos ateremos à análise de narrativas visuais que a entrevistada produziu em contexto ritualístico. Especificamente, a composição de três vestimentas para festas de orixás e entidades da umbanda (lemanjá, Oxum e Pombagira) no terreiro ao qual ela pertence. $E$, ainda, sobre o relato de preparação de uma comida ritualística chamada omolocum, ofertada ao orixá Oxum, deusa regente da cabeça de Inês.

Inês é uma senhora de sessenta e nove anos que migrou de Caiana dos Crioulos, comunidade quilombola localizadas em Alagoa Grande-PB, para João Pessoa, aos dez anos de idade, após a morte dos pais adotivos. Inês trabalhou como empregada doméstica na casa de famílias ricas da cidade, como a do jornalista Virginius da Gama e Melo.

Iniciou a trajetória na religião da Jurema aos dezesseis anos, seguindo os preceitos de seus pais adotivos que tinham uma casa de Catimbó. Apesar de frequentar terreiros cujos toques de tambores escutava das casas onde trabalhava, foi em uma casa de Jurema, localizada no bairro da Torre, local mais distante de onde morava, que Inês se estabeleceu como filha da sacerdotisa D. Maria das Almas, tendo participado desta casa durante mais de 50 anos.

A trajetória de vida dessa mulher perpassa épocas históricas de repressão aos cultos afro-brasileiros e indígenas, xangôs e catimbós que eram proibidos pela lei, assim como por espaços de exclusão de poder na cidade de João Pessoa, como o bairro do Róger e o centro político e administrativo da cidade, locais por onde Inês realizava suas andanças, inicialmente como empregada na casa de famílias ricas de João Pessoa e, depois, como encarregada de obrigações de santo.

Apesar de todas as dificuldades e dos marcadores sociais de diferença que se impõem sobre o corpo, a vida e a história de Inês, sua narrativa não nos permite dizer que estas dificuldades e violências a imobilizaram de alguma maneira, ou que ela tenha aberto mão, em algum momento, de assumir o lugar de sujeito de sua história. Pelo contrário, Inês sempre entendeu que estar viva é estar em movimento e sempre lutou para ter direito ao movimento e à liberdade de estar no mundo conforme seus próprios preceitos.

Interessa-nos, portanto, entender através das suas narrativas de vida, a relação do corpo desta mulher com a dinâmica da cidade que, historicamente, foi construída para inviabilizar o pertencimento e a própria existência de vidas como a de Inês.

\section{O CORPO NEGRO E OS MODOS DE NARRAR A VIDA}

Tendo em vista os processos de cruzamento entre as religiões afro-ameríndias no estado da Paraíba e em todo o território brasileiro, entendemos que os terreiros de Jurema e Umbanda se inscrevem dentro do patrimônio cultural do negro brasileiro, conforme elucidou Muniz Sodré (2019), ao tratar do terreiro enquanto forma social negro-brasileira.

Esses lugares apresentam-se como possibilidade de se "reterritorializar" na

"diáspora através de um patrimônio simbólico consubstanciado no saber vinculado 
ao culto dos muitos deuses, à institucionalização das festas, das dramatizações dançadas e das formas musicais" (SODRÉ, 2019, p. 52).

Apesar do processo de assimilação de elementos da cultura indígena brasileira, e do espiritismo kardecista, a Umbanda e Jurema, em seus processos de reelaborações simbólicas, são majoritariamente devedoras de culturas e visão cosmológicas de mundo dos povos africanos de procedências étnicas Nagô (Yorubá). Estes povos foram sequestrados da região do Golfo da Guiné, ou Baixa Guiné, região da qual fazem parte países como Costa do Marfim, Gana, Togo, Benim, Nigéria, Camarões, Guiné Equatorial e Gabão e que, antigamente, correspondiam aos reinos de Benin, Daomé e Ashanti.

Partindo de princípios cosmológicos nagôs advindos dos candomblés, que se estendem amplamente às Umbandas cruzadas com Jurema, a vivência do transcendente se dá através de rituais e transe que colocam a comunidade em contato com os Orixás e outras entidades do universo afro-ameríndio. Diferente de visões cosmológicas judaico-cristãs, nas quais o reino de Deus está em um lugar não terreno, o mundo nagô é o próprio planeta terra. Elementos naturais e físicos são constituintes divinos, como, por exemplo, a lava dos vulcões é o corpo vivo de Xangô, o mar é o corpo materno de lemanjá e o rio é o corpo de Oxum.

Esse princípio leva à compreensão do corpo humano, dentro de tal configuração simbólica, como permeado por um mundo histórico, o mundo da modernidade ocidental e suas dinâmicas organizacionais, mas, também, como um mundo cosmo mítico que coloca a pessoa em diáspora em contato com uma rede de significações muito profundas. A este respeito, Muniz Sodré (2018) disserta sobre como a memória mitológica opera:

\begin{abstract}
A memória "mitológica", porém, não consiste em um corpo doutrinário articulado, portanto, em nenhuma exposição dogmática nem raciocínios formais e sim em um repertório cultural de invocações, saudações, cantigas, comidas, lendas parábolas e símbolos cosmológicos, que transmite de forma iniciática no quadro litúrgico do terreiro e, no âmbito da sociedade global, expandindo-se nas descrições assim como nas interpretações escritas ou livrescas. $(2018$, p.96)
\end{abstract}

Em Memória e Patrimônio em Arquivo Vivo (2018), Maria Antonieta Antonacci argumenta que a memória e a história de povos africanos ou em diáspora emergem em agenciamentos que impactam o "drama do saber" das civilizações ocidentais e que, assim sendo, o corpo das pessoas em diáspora é arquivo vivo. A memória dos povos africanos e ameríndios em diáspora, segundo esta autora, se expressa através de escritas do próprio corpo, nos quais o conhecimento é transmitido de geração em geração:

Só mais recentemente textos, pesquisas acadêmicas, traduções vem abrindo perspectivas que povos africanos em diáspora, em função de seus universos e práticas culturais, aqui chegaram com memória do corpo. O dramaturgo nigeriano Esiaba Irobi, em diálogo com estudos do tráfico atlântico, argumentou que africanos "sobreviveram à travessia do Atlântico trazendo consigo escritas performativas, veiculadas a transmissão de geração a geração por meio da inteligência do corpo humano". Como a "ontologia da maioria de povos africanos é primordialmente espiritual, o corpo físico importa, 
em certo nível, hábitos memoriais, atividades são inventadas e praticadas. (ANTONACCI, 2018, p. 83)

Tendo em vista a forma como a memória mitológica destes povos se inscreve no corpo, como observamos, nos interessam os pontos cantados, preces faladas, estórias, contos e anedotas, narrativas míticas ou de vivências da Umbanda e da Jurema Sagrada. Não buscamos na pesquisa "coletar" um depoimento e tratá-lo de maneira a analisar a carga de veracidade histórica do que estava sendo dito. A perspectiva adotada foi a de compreender tudo o que Inês nos contou e nos ensinou em seu próprio contexto de produção de sentido e modo de subjetivação. Modo de subjetivação este que opera em planos materiais e no plano dos encantados.

Nos interessa neste trabalho, também, o conceito de Literatura Menor, pensado por Deleuze e Guattari (2017). Os autores trabalham a ideia de uma escrita menor dentro de uma língua oficial, como foi a escrita de Kafka e da comunidade dos judeus que habitavam em Praga e precisavam escrever em alemão: "uma literatura menor não é a de uma língua menor, mas antes a que uma minoria faz em língua maior. Mas a primeira característica, de toda maneira, é que nela, a língua é afetada de um forte coeficiente de desterritorialização." (p.35).

A literatura menor desterritorializa o idioma nacional, pois, sabemos, o idioma em um país como o Brasil, em contexto de herança colonial, é um símbolo pátrio carregado de ideologias e tecnologias coloniais. A estigmatização da voz de pessoas marginalizadas é, portanto, um instrumento de promoção de injustiça cognitiva e social. A voz das pessoas afro-ameríndias carrega diferenças e marcas de suas identidades que conflitam com o idioma que lhes foi imposto. A esse respeito Deleuze e Guattari formulam o seguinte:

Quantas pessoas hoje vivem em uma língua que não é a sua? Ou então não conhecem mais a sua, ou ainda, conhecem mal a língua maior de que são forçados a se servir? Problemas dos imigrados, e sobretudo de seus filhos. Problema das minorias. Problema de uma literatura menor, mas também para nós todos: como arrancar de sua própria língua uma literatura menor, capaz de escavar a linguagem, e de fazêla escoar seguindo uma linha revolucionária sóbria? Como devir o nômade e o imigrante e o cigano de sua própria língua? Kafka diz: roubar a criança no berço, dançar cobre a corda bamba. (2017, p. 4041)

O preconceito religioso no Brasil opera de forma a estigmatizar os sentidos e a linguagem das culturas populares afro-ameríndias. Termos como macumba e catimbó significam, no imaginário coletivo da nação, adoração ao demônio cristão, causando profundo alheamento e violência simbólica contra a comunidade juremeira e umbandista. Neste sentido, Deleuze e Guattari abordam o caráter político de uma literatura menor:

A segunda característica das literaturas menores é que tudo nelas é político. Nas "grandes" literaturas, ao contrário, o caso individual (familiar, conjugal, etc.) tende a juntar-se a outros casos não menos individuais, o meio social servindo de meio ambiente e de pano de fundo de maneira que nenhum desses casos edipianos é indispensável em particular, absolutamente necessário, mas que 
todos "fazem bloco" em espaço largo. A literatura menor é completamente diferente: seu espaço exíguo faz que cada caso individual seja imediatamente ligado à política. O caso individual torna-se, então, tanto mais necessário, indispensável, aumentado ao microscópio, quanto toda uma história se agite nela. (2017, p. 36)

Assim sendo, entendemos que a resistência do povo de santo ao embranquecimento e cristianização de seus símbolos adquire caráter político quando estes símbolos são falados, cantados ou escritos e inscritos nos corpos de homens e mulheres, vítimas da intolerância religiosa. A voz e o corpo de um juremeiro ou juremeira partem da esfera individual, mas assumem a esfera coletiva, pois desafiam os padrões impostos ao seu povo.

Pensando a partir da memória mitológica que o corpo de pessoas juremeiras carrega, o sagrado opera de forma também a se manifestar através de diversos sinais físicos, muitas vezes chegando a se expressar até mesmo através de doenças espirituais que só podem ser curadas em rituais iniciáticos. Isso pode ser observado nos relatos orais de Inês.

Durante as conversas ela nos fala que desde criança queria fazer a iniciação na Jurema, quando ouvia escondida aos Catimbós de seus pais. Porém, quando estava na idade de iniciação seus pais adotivos faleceram e ela precisou migrar para João Pessoa e viver em casas de famílias muito católicas, impossibilitando sua iniciação religiosa. Apenas com quinze anos é que ela conheceu os terreiros da cidade:

Quando eu vim mesmo, tomar o entendimento mesmo, para participar, já estava com meus quinze anos, mais ou menos. Quinze anos, dezesseis anos, é tanto que minha primeira obrigação, quando eu fiz minha Jurema, eu tinha dezesseis anos. Quando eu fiz minha primeira Jurema... aí depois, depois de dezesseis anos, com dezesseis anos eu fiz, quando foi depois de três anos aí eu já dei meu laô. Eu tinha muito problema, era doente, aí eu tive que fazer essas obrigação. Aí pronto: fiz as obrigações e melhorei e depois continuei, né? Fiquei na gira, até hoje eu ainda giro, uma vez por outra, quando eu não estou muito cansada, eu vou.

Percebemos no trecho transcrito acima como as doenças que acometiam o corpo de Inês eram sinais de que ela estava em dívida com o plano espiritual. Após realizar as obrigações que a iniciaram na Jurema ela melhorou e continuou sua trajetória de vida de juremeira, participando das giras, prática efetuada até hoje. Parece-nos que mensagens como estas que Inês relatou de sua iniciação são comuns em sua vida. Em uma das festas que presenciamos Inês teve um mal-estar e precisou sair da gira. Dias depois ela nos contou que o fato ocorreu porque ela estava em dívida com um de seus santos e que, naquele momento, ele veio cobrar essa obrigação. É muito coerente que o corpo seja uma via de contato tão intensa com o seu santo ao ponto de em alguns momentos a pessoa juremeira desfalecer, pois o corpo nesta religião é receptáculo e é também o suporte para as batalhas e glórias, frutos da relação com as entidades da Jurema.

A relação de vitalidade, energia e força, "a força da jurema", desenvolvida através dos rituais, é um princípio organizativo também correspondente à visão 
cosmológica dos Yorubás do axé, uma corrente de poder a partir da subordinação de um indivíduo ao conjunto de práticas da jurema, "a ciência da jurema". Essas práticas consistem na construção de experiências iniciáticas dinâmicas no coletivo religioso, que não existem de forma individualizada, mas sempre em conexão com uma hierarquia de laços desenvolvidos nos terreiros.

Muniz Sodré (2019) compreende o axé, além de uma força, também como:

um princípio-chave de cosmovisão. O Axé, diz Juana Elbein, "assegura a existência dinâmica, que permite o acontecer e o devir. Sem axé, a existência estaria paralisada, desprovida de toda possibilidade de realização. É o princípio que torna possível o processo vital". Pode-se usar aqui a explicação de Jung relativa a outro contexto: "Não é o supranormal, mas o eficaz, o poderoso, o criativo". A energia do Axé acumula-se e transmite-se por meio de determinadas substâncias (animais, vegetais, minerais, líquidas), sendo suscetível de alteração, a depender das variadas combinações dos elementos que se compõe. Há, portanto, vários tipos de axé. (2019, p. 89)

Além de doenças, desfalecimentos e curas que têm uma dinâmica própria dentro da jurema, podemos perceber marcas nos corpos dos juremeiros e umbandistas que remetem aos comportamentos miméticos relacionados às narrativas mitológicas dos Orixás e de outras entidades das religiões afroameríndias. Por exemplo, quando uma pessoa é recebida como filho por um determinado Orixá é comum a transferência gestual e de personalidade para aquela pessoa: diz-se de uma filha de Oxum que esta pessoa seja graciosa e melindrosa, ou que de um filho de Xangô é comum esperar gestos abruptos e incisivos.

Como argumentou Boaventura de Sousa Santos (2019), o corpo tem potencialidade narrativa tal qual outras formas de expressão e de busca de conhecimento. É, pois, neste sentido que buscamos "ler" a construção de narrativa do corpo de Inês. A escrita performativa que Inês desenvolve no cotidiano com o seu corpo reflete, diretamente, aquilo que durante todos estes anos ela aprendeu e viveu na Jurema Sagrada. Pois, não sendo a liturgia da Jurema escrita, a forma como estes corpos guardam os preceitos da religião é de grande importância. Ainda segundo Antonacci:

Sant'Anna, em entrevista a Vigarello, abordando o potencial do corpo, que "pode representar dimensões bastante diferentes da vida", sendo "por meio dele que nós revelamos como o mundo é construído", contempla questão vital a estudos voltados à memória do corpo em culturas orais: "Em certas situações, especialmente quando a relação com a escrita e com o livro não é geral, o corpo pode revelar uma profundidade social por vezes inimaginável; o corpo é arquivo vivo em várias culturas. " $(2018$, p. 86)

É o corpo como memória viva que se coloca à disposição dos mestres e mestras da Jurema. Fazem parte desse corpo também o conhecimento e a ciência necessários para prosseguir nas trajetórias dos filhos de santo nos terreiros da vida. Entender esse aspecto é crucial, pois a Jurema e a Umbanda não respeitam o binário espírito/corpo que foi essencial para edificar a fé cristã no ocidente, cujo 
objetivo central era salvar o espírito para Deus, livrando-o dos males e paixões do corpo.

A forma como os rituais da Jurema e da Umbanda se organiza é um exemplo de como essas religiões destinam importância aos prazeres e sentidos carnais, conferindo ao corpo status ontológico de contato com o sagrado. Festas, giras, toques, são sempre nomes alusivos ao prazer, à dança e à comunicação com o sagrado por outras vias dos sentidos humanos e corpóreos. Em uma das nossas conversas Inês nos fala de uma festa de Exu e Pombagira:

Vai ser muito bom o toque lá, tanta da Pombagira, tanta da Pombagira que enterra... menina, tudo no preto e no vermelho. Tomando champanhe, de beber, é para beber mesmo! Eu que não vou beber. Eu não bebo mesmo, só tomo água e olhe lá. Talvez eu só vá a beber um pouquinho no dia do meu aniversário, mas estou sem poder beber nada, minhas taxas tudo alta, colesterol lá em cima, não vou fazer extravagancia, tenho que me cuidar, né, menina? Que bebida todo tempo tem e a saúde... a gente tem que cuidar da saúde, mesmo.

A festa que Inês menciona no trecho citado ocorreu no dia primeiro de agosto de dois mil e dezenove. As faceiras e provocantes entidades Exu e Pombagira, homens e mulheres que vestiam preto e vermelho no salão do terreiro naquele dia, festejaram, comeram, beberam e fumaram.

Sousa Santos (2019) argumenta que o júbilo do corpo, tal qual acontece nas festas dos terreiros, é essencial para que os povos oprimidos continuem firmes em suas jornadas:

A dança e o canto têm um valor epistemológico crucial para as epistemologias do Sul. Dados os seus pressupostos judaico-cristãos, as epistemologias do Norte estão permeadas de ideologias de culpa e melancolia. Têm grande relutância em valorizar as dimensões cognitivas da festa e da celebração alegre, exceto quando ocorrem em contextos socialmente regulados, como em casamentos ou festas calendarizadas, sejam religiosas ou não. É evidente a existência de uma aversão a reações viscerais potencialmente explosivas, dada a importância do equilíbrio, da neutralidade e da distância que os corpos devem manter a fim de facilitar o trabalho do sujeito epistêmico. Para as epistemologias do Norte, só ao poeta é permitido ser suficientemente louco para pensar que o excesso conduz ao palácio da sabedoria. Pelo contrário, as epistemologias do Sul entendem a alegria, o júbilo, a celebração e a festa como expressões da força vital exigida pelas lutas contra a opressão. (2019, p.137)

Nas festas que acompanhamos com a presença de Inês, o caráter de júbilo e de partilha foi algo que nos chamou a atenção. $O$ cuidado que os irmãos da casa têm uns com os outros, os processos de escuta e trocas de afetos e práticas de cura mostraram que a comemoração que ocorre nos terreiros é realmente uma proposta de sociabilidade que atenta aos valores utilitaristas que o ocidente colonial estabeleceu como formas legítimas de socialização. 


\section{COMIDAS E ROUPAS DE SANTO: OUTRAS FORMAS DE SABER}

Em O fim do império cognitivo (2019), Boaventura de Sousa Santos traça possíveis rotas para afirmações das produções epistemológicas do povo do Sul Global. Entre as metodologias pós-abissais o autor advoga a necessidades de uma experiência profunda com os sentidos, pois o conhecimento não é possível sem a experiência e a experiência é inconcebível sem os sentidos. É pensando nisso que o autor fala em visão profunda por parte dos pesquisadores não abissais:

A visão profunda implica que o investigador pós-abissal esteja disposto a "ver' o que efetivamente não vê e sim aquilo que sabe ou presume que o grupo vê no que se refere a si pessoalmente. Tem plena consciência de que a forma como trata essas assimetrias do ver decidirá o destino do conhecer-com e da partilha da luta. O próprio investigador é, por assim dizer, um mapa atravessado pela linha abissal; o seu projeto de conhecer-com tem de incluir a cura da ferida causada pela linha abissal, sob pena de o seu trabalho deixar de ser aquilo que afirma ser (um projeto de investigação pós-abissal). (2019, p.249)

Temos em mente que para efetivar a visão profunda precisamos descolonizar nossos olhares para buscar compreender o contexto de vida de Inês dos Santos e de sua produção de conhecimento. Não buscamos aqui romantizar ou exotizar o que temos visto, buscamos, ao contrário, olhar com Inês para a sua própria história.

O plano visual nas religiões afro-ameríndias tem importância elementar, como já foi mencionado anteriormente, sobre a capacidade dos corpos de manterem-se como arquivos vivos da tradição. Neste tópico buscaremos abordar especificamente como a construção narrativa se dá através da criação da atmosfera visual nos terreiros. Analisaremos aqui como isso se dá por meio das comidas e vestimentas. Pensando nisso é que as considerações de Roland Barthes (2009) sobre a significação da vestimenta no sistema de moda nos interessam para buscarmos entender a construção da narrativa através das roupas de santo, e, também, como isso pode ser aplicável às comidas, como veremos adiante:

Quando o seu significado é explicito, o código indumentário recorta o mundo em unidades semânticas das quais a retórica se apodera para "vesti-las", ordená-las e, a partir delas, construir uma verdadeira visão de mundo: noite, fim de semana, passeio, primavera são unidade erráticas que, embora provenientes do mundo, não implicam nenhum "mundo" particular, alguma ideologia definida, motivo pelo qual nos recusamos a classifica-las no código indumentário. Essa construção retórica do mundo, que poderia ser comparada a uma verdadeira cosmogonia, é feita por duas vias principais (já indicadas quando falamos do significante retórico): metáfora e parataxe. (2009, p.365)

No trecho acima, Barthes argumenta como a vestimenta pode ser uma unidade semântica a depender da forma como a retórica se apropria dela. $\mathrm{O}$ autor opõe as práticas cotidianas de vestuário, que são corriqueiramente ocasionais, à uma forma de construir significado através de metáforas que expressem uma 
cosmogonia, como entendemos que seja o uso das roupas de santo nos rituais religiosos.

A vestimenta para o santo assume um lugar muito importante na vida de Inês, talvez por seu Orixá ser tão vaidoso:

Inês: Hoje em dia eu não coloco mais muita roupa como eu botava, não...

Maria: Cooooloca Inês, Inês.

Inês: [risos] Eu colocava 10 saias na época de primeiro, tudo na goma...Agora eu não aguento mais.

Maria: É muito importante, né? Para Oxum, esses enfeites...

Inês: Oxum é o orixá que se enfeita muito, é o orixá que mais tem enfeite é Oxum, é a dona do ouro, é a dona do dinheiro, é a senhora do amor... tudo é Oxum, menina. Oxum é quem domina tudo. A dona dos rios, dos Lagos, tudo é Oxum...Oxum domina muito, muito mesmo.

Maria: Por isso que tu é bonita e vaidosa desse jeito, né, Inês? Inês: Pois é, eu gosto muito de ser filha de Oxum, eu gosto de todos os orixás, obvio... mas, meu orixá pra mim é tudo. Eu nem me enfeito mais, mas eu já me enfeitei tanto.

No trecho citado podemos entender a dimensão que a vestimenta assume na vida dela, pois sua identidade foi forjada em consonância com a visão cosmológica da Jurema Sagrada. Não apenas as roupas que se referem ao orixá Oxum têm importância para Inês, mas em outros momentos vividos na religião ela faz referência sempre à roupa que estava usando, como no ritual de sua iniciação:

Minha primeira roupa eu ainda lembro como se fosse hoje, ele mandou eu fazer uma roupa branca, uma blusa branca e uma saia branca. Meu primeiro traje foi branco, ele exigiu mesmo. Aí eu fique esse tempo todinho lá, muito tempo mesmo com ele.

Em nossas conversas falas como essas são muito comuns, Inês sempre remete ao tipo de roupa que estava usando no momento da festa em questão, por exemplo quando ela fala que era uma festa de Exú e Pombagira ela sempre completa: "todo mundo girando de preto e vermelho no salão".

Desde o início do nosso percurso durante a pesquisa, quando começamos a visitar Inês, pudemos acompanhar três festas no terreiro que ela frequenta: uma festa para lemanjá no dia 7 de dezembro de 2018, véspera do dia 8 de dezembro de 2018, pois esse foi o dia que a comunidade dos povos de terreiros da cidade de João Pessoa escolheu para louvar lemanjá, tendo em vista o sincretismo religioso que ocorre nessa cidade, já que esse é também o dia de Nossa Senhora da Conceição; uma festa de saída de Santo para Oxum, obrigação de uma afilhada de santo de Inês, no dia 25 de Julho de 2019 e, ainda, uma festa para Exú e Pombagira no dia primeiro de agosto, chamada 'Noite negra', pois essa é a festa que inaugura as atividades do terreiro no mês de agosto, mês dedicado ao Orixá Exú, em sua face macho e fêmea.

Nas três festas que acompanhamos, as roupas de Inês contavam uma história sobre as entidades que ela reverenciava. O conteúdo mimético da vestimenta expressava na festa de lemanjá uma roupa clara e opulenta como é caracterizada 
a dona dos mares. A roupa de Inês era toda branca dos pés à cabeça, mas também toda trabalhada em bordados e detalhes ricos; na celebração para Oxum, Inês utilizava muito ouro e roupas amarelas e brancas, portava muitos enfeites, conforme as lendas do Orixá referenciam; a noite dedicada à Pombagira contrastava com as duas anteriores, a opulência da vestimenta de Inês remetia ao caráter das pombagiras: um vestido preto estampado com bordados de rosas (a rosa vermelha é um símbolo da Pombagira) e ainda com detalhes em dourado e vermelho. Podemos ver os detalhes das roupas nas imagens que seguem, feitas nas festas de lemanjá, Oxum e Pombagira, sucessivamente:

FIGURA 1 - Roupas de Inês nas Festas de Iemanjá, Oxum e Pombagira

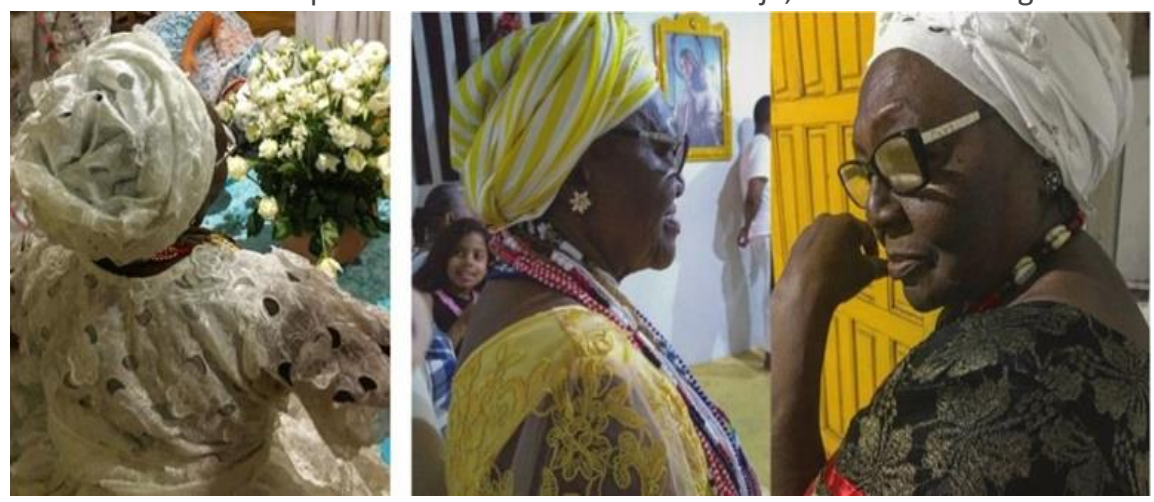

Fonte: Acervo pessoal das autoras. Imagens autorizadas por Inês dos Santos.

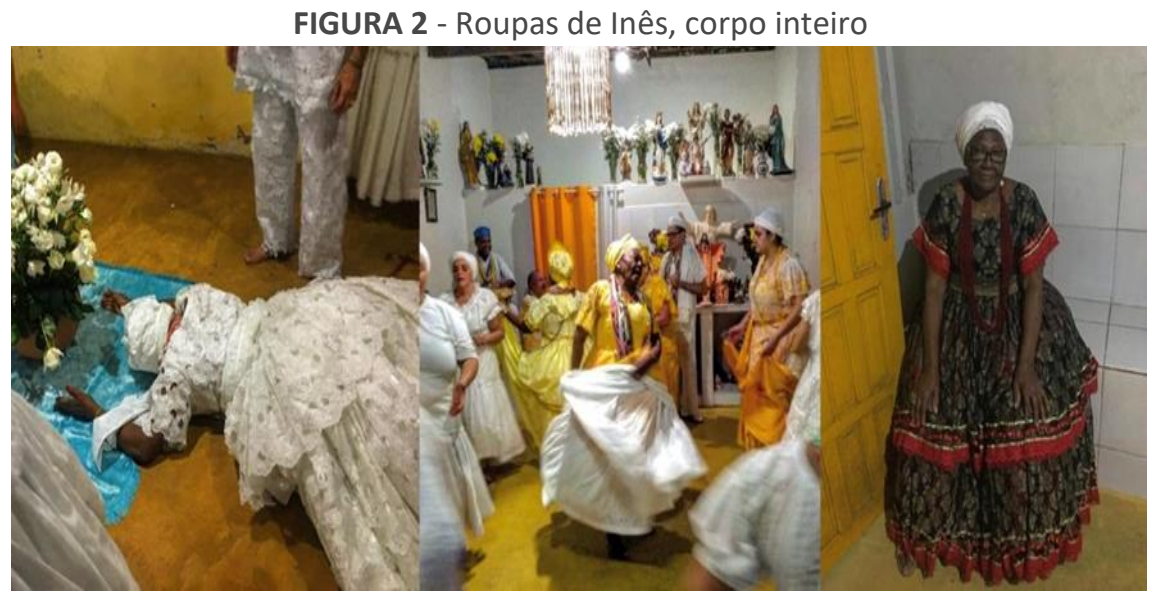

Fonte: Acervo pessoal das autoras. Imagens autorizadas por Inês dos Santos.

Dessa forma, podemos perceber o caráter poético das roupas usadas nas cerimônias. A atmosfera ritual é permeada por símbolos que os adeptos vestem para que em cada gira a história das entidades seja contada. Ainda pensando com Barthes, podemos entender as roupas de santo como objetos poéticos:

Pode-se esperar que o vestuário constitua um excelente objeto poético; em primeiro lugar, porque mobiliza com muita variedade todas as qualidades da matéria: substância, forma, cor, tatilidade, movimento, porte, luminosidade; em segundo lugar, referindo-se ao corpo e funcionando ao mesmo tempo como substituto e máscara dele, o vestuário certamente é objeto de grande investimento; essa 
disposição "poética" é comprovada pela frequência e qualidade das descrições indumentárias na literatura" (2009, P. 350-351)

Além da vestimenta, nos deteremos sobre outra unidade semântica muito importante na construção narrativa mítica dentro dos terreiros de jurema: as comidas rituais. Pensar a alimentação a partir da dinâmica diaspórica dos povos afro-ameríndios enseja-nos diversas questões de ordem sociológica sobre vozes e corpos silenciados.

Maria Paula Meneses (2013) aventou a possibilidade de analisarmos a preparação de alimentos, o ato de cozinhar, a partir de sua dimensão política, através da cozinha moçambicana durante os processos da luta pela libertação do colonialismo. A autora entende que a atividade humana combina conhecimentos e práticas mutuamente inteligíveis para diferentes sociedades e grupos identitários. Pensar o ato de cozinhar, a partir de um ponto de vista filosófico, segundo a autora, valida novas categorias de questionamentos, tendo em vista que a prática é, em si mesma, uma forma de saber.

Nas festas, giras ou toques de Jurema, no cenário comunicativo, predominado pelo comportamento não verbal das pessoas envolvidas, embora haja pontos cantados e conselhos e repreensões do pai de santo, recebem destaque as experiências comunitárias. É neste sentido que as comidas e bebidas compartilhadas representam uma experiência de conexão coletiva com as entidades festejadas.

Da mesma maneira que as roupas têm importância dentro dos rituais, a comida também funciona como unidade semântica. llustrativo disso é um momento da entrevista em que Inês nos explica como vai fazer a comida que irá oferecer para o seu Orixá que está Ihe cobrando uma obrigação:

Ana: Mas com comida seca faz... comida seca é o quê?

Inês: Comida seca é muita coisa, a comida seca pega, comida seca pega camarão, pega rabada, você sabe o que é rabada? (para Ana)... rabada de Xangô, que volga pelo bicho de quatro pé, omolocum pra Oxum que é feito com feijão macassa, que faz o omolocum, aí a gente prepara o prato que fica como um girassol, pega ovo, feijão macassa, pega dendê, pega mel, pegatudo... né?! Para o de Oxum.

Maria: Tudo amarelo, né?

Inês: Tudo amarelado. Aí a gente faz no alguidarzinho branco, de louça branca, né? Aí faz tudo direitinho, corta as tirinhas do ovo cozinhado tudinho, bota assim tudo em cima, em cima depois que o feijão tá todo machucado, todo arrumadinho dentro do pirex. Aí depois pega mermo ele ainda aí bota a gema do ovo pra cozinhar só, aí é o omolocum.

Ana: Ai que lindo!

Inês: Aí fica o omolocum mesmo. $\mathrm{O}$ omolocum pra Oxum. Aí vou fazer arroz doce, fazer milho branco, milho vermelho... como, é? Todo tipo de fruta pega! Bolo! Pega muita coisa, pega coisa de mais fia. Apesar que fica uma obrigação mais cara do que se você cortasse ...

Ana: Né isso?! 


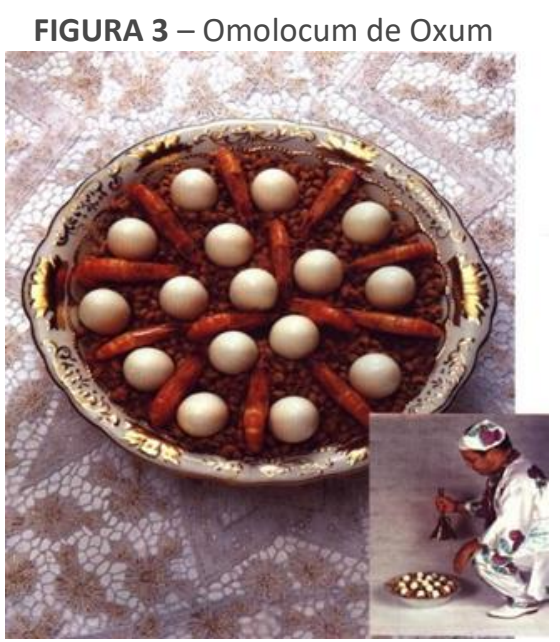

Fonte: Wikimedia

Fica explícita a construção da narrativa visual na feitura do prato que vai ser oferecido ao orixá Oxum. Feijão, mel, gema de ovo, azeite de dendê e camarão não são comumente servidos juntos, mas Inês, no papel de devoção ao seu Orixá, organiza estas comidas de modo a construírem a imagem de um girassol, flor dedicada ao orixá. Consequentemente, percebemos que a feitura da comida funciona como símbolo mítico no ritual.

Voltando aos questionamentos de Meneses sobre a potencialidade narrativa das comidas e da cozinha decolonial, nos parece interessante para a presente discussão a potência narrativa deste tipo de construção apontada pela autora:

Como fazer para que as receitas sejam lidas como textos históricos e
textos literários? Como legitimar este saber? [...]. A par e passo, a
receita vai indicando a sequência e ordem das ações necessárias e
apropriadas para que o objetivo final - o prato cozinhado - seja
atingido. Para ampliar as Epistemologias do Sul: verbalizando sabores
e revelando lutas. Neste sentido, é um texto organizado, expressando
uma narrativa. As receitas são uma forma de as mulheres criarem a
sua história - pela oratura, pela escrita, pelos cozinhados -,
produzindo um arquivo de epistemologias específico. Porque as
receitas encerram "histórias que esperam ser contadas" (White,
1980: 6) com coerência, integridade, completude e finalidade, a sua
interpretação contribui para ampliar saberes, até agora
desconhecidos ou invisibilizados. (2013, p.09)

Devemos levar em conta que dentro da tradição da Jurema, do ponto de vista ritual, a cozinha não é essencialmente um lugar reservado às mulheres. Entretanto, se pensarmos como dinâmica ocidental da divisão sexual e racial do trabalho, essa experiência atravessa a vida de mulheres juremeiras como Inês, cuja história está ligada ao trabalho de cuidado e cozinha. Podemos perceber como a produção de narrativas outras, através de comidas e vestimentas, nos ajudará a reclamar outros lugares para as narrativas de mulheres que não sejam os mesmos relegados pela biblioteca colonial. 


\section{CARTOGRAFIA EM PROCESSO}

A narrativa de vida de Inês, juremeira da cidade de João Pessoa, foi o objeto do nosso interesse de pesquisa no presente artigo. Entendemos que este trabalho é relevante para o meio acadêmico, tendo em vista a forma como historicamente a academia relegou ao lugar de marginalização saberes e narrativas advindas de povos marginalizados socialmente.

Nos relatos de Inês, nota-se o labor empregado em construir um sentido existencial a partir de uma visão cosmológica específica dos povos que vivem a diáspora afro-ameríndia em nosso país. As diversas formas de (re)construir sua memória mítica nos interessam, pois entendemos que precisamos nos libertar das amarras acadêmicas, a partir do descentrar da produção de conhecimento e de uma história relacional, com múltiplas interpretações.

O conteúdo simbólico produzido pelas pessoas que vivem a dinâmica da cidade cotidianamente, a partir de lugares de precariedade, é negligenciado pela história e pela literatura oficial. Essas memórias vivem em constante perigo de destruição. Assim sendo, pensar a memória como construção narrativa, implica entender também o viés político que esses processos de subjetivação enfrentam. Constituir-se como sujeito de sua própria vida exige que as pessoas se tornem inteligíveis perante a sociedade da qual fazem parte. Os relatos de vida são investimentos políticos, principalmente quando pensamos o contexto de opressão estrutural do qual multidões de vozes emergem.

Nesse sentido, as memórias de Inês, a participação nas atividades do terreiro e a contrução coletiva de narrativas feitas também a partir do corpo (roupas) e dos alimentos (comidas de santo), nos possibilitam traçar novas cartografias para uma cidade como João Pessoa, que insiste em esconder o trabalho invisível produzido por mulheres racializadas (VERGÈS, 2020).

Não buscamos estar neutras diante do apreendido em nosso campo, pois entendemos que não existe uma correlação de poderes simétrica na sociedade de herança colonial, patriarcal e capitalista em que vivemos. Existem, isso sim, grupos que historicamente foram marginalizados pelos poderes que formam o conjunto da nossa sociedade. Assim sendo, escolhemos ficar ao lado e aprender com os grupos cuja ausência ainda é uma realidade, quando pensamos a construção de cidadania plena em nosso país. Não buscamos ficar distantes também por entender que o positivismo acadêmico é apenas um fetiche que aparta o pesquisador da realidade. Para nós, interessou mais a troca de afetos como processo genuíno de compartilhamento de experiências, pois, no contexto das entrevistas e da temática que estávamos analisando, Inês tinha muito mais - ou simplesmente tudo - a nos ensinar e nós tínhamos tudo a aprender.

O que se relatou nestas páginas foi a tentativa parcial de apreender uma miríade das inúmeras experiências que o campo de pesquisa dos terreiros de Jurema da cidade de João Pessoa tem nos oferecido através do relato de vida de Inês dos Santos. 


\title{
Annunciation of worlds, dreams and ancestral knowledge: narratives of a juremeira from the city of João Pessoa
}

\begin{abstract}
The present work involves research on the life history and the paths of juremeira Inês dos Santos in the city of João Pessoa, Paraíba. We are interested in understanding, from Inês's experience, how the collective narratives of Jurema and Umbanda terreiros (re) build the mythical memory (Sodré, 2018) of populations in Afro-American diaspora contexts in this city. In this sense, we are also interested in ritualistic clothes and foods as narrative constructions. We use the concept of Minor Literature (DELEUZE and GUATARI, 1995) to understand Inês' narratives, according to her ethical and political imperatives, and we also use concepts from cultural, feminist and decolonial studies, authors who have worked on themes as "coloniality" and "decoloniality", "diaspora", "epistemicide", "social and cognitive justice" (FANON, 1968; QUIJANO, 2005; SOUSA SANTOS, 2019). We adopted field research methodologies focused on oral history, as an interview technique, and testimony, as a social and political posture so that, in the end, we can draw a cartography of the city built from the voice and body of this black woman, daughter of Oxum and devotee of the enchanted Jurema.
\end{abstract}

KEYWORDS: Oral narrative. Holy Jurema. Umbanda. Cartography. 


\section{NOTAS}

${ }^{1}$ Disponível em: https://commons.wikimedia.org/wiki/File:Omolocum.jpg

\section{REFERÊNCIAS}

ANTONACCI, Maria Antonieta. Memória e patrimônio em "arquivo vivo". Projeto História, São Paulo, v. 62, Mai-Ago, pp. 80-110, 2018.

ASSUNÇÃO, Luiz. Os Mestres da Jurema. In: Encantaria brasileira: o livro dos mestres, caboclos e encantados / Reginaldo Prandi, organizador; textos de André Ricardo Aguiar de Souza et al. Rio de Janeiro: Pallas, 2011, p. 182 - 215.

BARTHES, Roland. Sistema de moda. São Paulo: Editora WMF Martins Fontes, 2009.

BUTLER, Judith. Quadros de guerra: quando a vida é passível de luto. Rio de Janeiro: Civilização Brasileira, 2015.

DELEUZE, Gilles e GUATARI, Félix. Kafka: por uma literatura menor. 1.ed. 3. reimp. Belo Horizonte: Autêntica Editora, 2017.

FANON, Frantz. Os condenados da terra. Rio de Janeiro: Editora Civilização Brasileira, 1968.

HALL, Stuart. Da diáspora: identidades e mediações culturais. Belo Horizonte: Editora UFMG, 2005.

LIMA SANTIAGO, Idalina Maria Freitas. A Jurema Sagrada da Paraíba. In: QUALIT@S Revista Eletrônica.ISSN 1677-4280 v.7, n.1, 2008.

MENESES, Maria Paula. Para ampliar as epistemologias do Sul: verbalizando sabores e revelando lutas. In: Configurações [Online], 12 | 2013. Disponível em: http://journals.openedition.org/configuracoes/1948; DOI: 10.4000/configuracoes.1948. Acesso em: 20 abr.2019. 
OMOLOCUM. In: Wikimédia Commons, 2004. Disponível em:

https://commons.wikimedia.org/wiki/File:Omolocum.jpg. Acesso em: 16 set. 2020 .

QUIJANO, Aníbal. A colonialidade do saber: eurocentrismo e ciências sociais. Perspectivas latino-americanas. CLACSO, Consejo Latinoamericano de Ciencias Sociales. Buenos Aires. 2005. Disponível em: http://bibliotecavirtual.clacso.org.ar/clacso/sur-

sur/20100624103322/12_Quijano.pdf. Acesso 30 jul. 2020.

SAMPAIO, Dilaine Soares. Concepções e ritos de morte na Jurema paiaibana. In: Religare, ISSN: 19826605, v.12, n.2, dez. 2015, p.344-369.

SODRÉ, Muniz. Pensar Nagô. Petrópolis: Vozes, 2017.

O terreiro e a cidade: a forma social negro brasileira. 3. ed. Rio de Janeiro: Mauad x, 2019.

SOUSA SANTOS, Boaventura de. O fim do império cognitivo: a afirmação das epistemologias do sul. 1.ed. Belo Horizonte: Autêntica editora, 2019.

Para além do pensamento abissal: das linhas globais a uma ecologia de saberes. Revista Crítica de Ciências Sociais, 78, outubro, 2007, p 3-46.

VERGÈS, Françoise. Um feminismo decolonial. São Paulo: Ubu Editora, 2020.

Recebido: 31 jul. 2020

Aprovado: 12 set. 2020

DOI: $10.3895 /$ rl.v22n38.12903

Como citar: MEDEIROS, Maria Gomes de; MARINHO, Ana Cristina. Anunciação de mundos, sonhos saberes ancestrais: narrativas de uma juremeira da cidade de João Pessoa. R. Letras, Curitiba, v. 22, n. 38 p. 15-33, set. 2020. Disponível em: <https://periodicos.utfpr.edu.br/rl>. Acesso em: XXX.

Direito autoral: Este artigo está licenciado sob os termos da Licença Creative Commons-Atribuição 4.0 Internacional. 